\title{
CHALLENGES IN THE CONTROL OF Aedes aegypti
}

\author{
Giovanini Evelim COELHO(1)
}

The unavailability of a vaccine to immunize the population against the four viral serotypes of dengue restricts prevention of disease to the performance of systematic combat to the only weak link in the chain of transmission, which is the mosquito Aedes aegypti ${ }^{1}$.

Despite the partial success obtained in the continental initiative to eradicate Aedes aegypti in the Americas in the early 40's, its control has proven to be a complex task over the past years.

In Brazil, the presence of Aedes aegypti is found in all regions and federal units of the country. A figure that shows the seriousness of the problem is the large number of infested cities in the country. Data provided by State Departments of Health shows that in just over a decade (1996-2009), there was a significant increase in the number of cities infested, from 1,753 cities in 1996 to just over 4,000 in $2009^{2}$.

With the backdrop of dengue fever worsening in the country, initiatives were launched by the Ministry of Health $(\mathrm{MH})$ in order to adequately address the problem. In this context, the National Program for Dengue Control (Programa Nacional de Controle da Dengue - PNCD) was launched and stands out based on the need to improve the quality of field work to combat the vector and to strengthen the epidemiological and entomological surveillance, in order to increase the predictive ability and early detection of disease outbreaks ${ }^{3}$.

One of the vector control activities recommended by both PNCD and programs from other countries ${ }^{4}$ is the home visit to carry out the inspection of deposits placed inside and around the residence, which are potential breeding sites of Aedes aegypti. One of the purposes of this activity is to obtain information on the larval density, estimated by the building infestation rate (BIR) and Breteau rate $(B R)^{5}$. Such rates have several limitations since it is excessively long (approximately 60 days) the duration of procedures used to obtain information on the levels of larval density, it does not consider the productivity of mosquito breeding and their sensitivity is low, compared to other methods of entomological assessment ${ }^{6}$. In addition, representative samples of the mosquito population are not used and the interpretation of the real meaning of their findings is hampered by entomological thresholds not defined for the risk of dengue epidemics ${ }^{7}$.

Several variables can explain the advance of mosquito infestation, both in Brazil and in the continent, and some are related to the biology and behavior of the vector, such as the ability to adapt and reproduce. Other factors include the limited impact of the current technological arsenal in the world, weather conditions and, undoubtedly, the infrastructure of basic services offered to cities in Brazil ${ }^{8}$.

The technology for vector control is mainly based on the use of environmental management measures for the suppression of mosquito breeding and the use of insecticides in a complementary way. The available insecticides target the larval forms in the daily activities of the agents of endemic diseases, and adult mosquito forms when transmission of the disease occurs.

Although absolutely required in specific situations, when insecticides are not properly used, this brings, among other consequences, the emergence of the resistance phenomenon for the strains of Aedes aegypti. In Brazil, the regular monitoring of 100 cities from different regions demonstrates the need for replacement of the insecticides in use. This problem affects large population areas, including major metropolitan areas of the country. The resistance issue in a large number of the cities, coupled with the fact of restricted supply of products that can be used instead, is currently an important challenge in the control of Aedes aegypti and, therefore, to combat dengue ${ }^{9}$.

Environmental factors are major macrodeterminants of maintaining the presence of Aedes aegypti and dengue virus circulation in the cities ${ }^{10}$. Among these factors, the lack of infrastructure in the cities with regard to the difficulties in maintaning regular services to ensure water supply and garbage collection on an ongoing basis is a major challenge. These two issues, when not fully met, restricts the city to a permanent situation of vulnerability, which mainly leads to offer highly productive mosquito breeding, such as the barrels and storage tanks for water supply and the existence of large amounts of artificial mosquito breeding in the environment such as plastic bottles, cans and other containers.

The 2008 report from the National Survey of Basic Sanitation (Pesquisa Nacional de Saneamento Básico (PNSB)) shows that, despite some advances, the urban infrastructure condition is still deficient in the Brazilian cities ${ }^{11}$.

Among the indicators analyzed by PNSB-2008, we highlight those aspects related to garbage collection and water supply. One concern is related to the capacity of the cities to carry out regular tasks of solid waste 
collection. Evaluating only the frequency of collection in the districts, $92 \%(4,856)$ of the cities reported to carry out this activity; however, only $39 \%(1,919)$ reported to be able to carry out this activity daily. This inability for frequent waste collection certainly represents a permanent situation of vulnerability to spread the breeding of dengue mosquito.

Another condition indicated in the research that increases the vulnerability to the maintenance of Aedes aegypti in our cities is regarding the regular supply of running water. Although at least $99 \%$ of the 5,564 cities surveyed are provided with water distribution network, unfortunately, this number does not translate in a condition that ensures continuous water supply at home. A significant number, 1,293 (23\%), of cities are affected by water rationing, determined by lack of water in their water sources, deficiency in the production or distribution and problems related to poor weather conditions, among others. The picture of water rationing occurs in all regions of the country, and is more severe in the Northeast area, where $40 \%$ of the cities faces this problem.

With all complexity involved in dengue control activities, which should involve joint actions within the health sector and also external actions in the resolution of infrastructure problems, it is natural that this program is very high cost ${ }^{12}$.

Despite the unfavorable results, some initiatives developed in recent years may increase the effectiveness of vector control measures and consistently impact dengue transmission.

Several technological innovations, in different levels of development, could be incorporated into programs for vector control. We highlight the traps to capture adult mosquitos, which could provide a better entomological indicator. Also, the perspective of supplying new insecticides and alternative use, such as the biological insecticide spinosad and the use of curtains and covers for water tanks impregnated with pyrethroids in the protection of breeding sites may constitute additional tools of control ${ }^{13,14}$.

Another aspect of great potential for use in the future is regarding the improvement to assess the impact of the control programs. In particular, the use of mathematical modeling starts to be highlighted and also the assessments conducted in order to assess the impact of the measures taken in epidemic situations ${ }^{15,16}$.

Finally a promising perspective that can contribute to the sustainable reduction of vulnerability of the cities are some government policies. In particular, the importance of works to expand the water supply from the Growth Acceleration Plan (Plano de Aceleração do Crescimento (PAC)) and the approval of the National Solid Waste Policy.

\section{REFERENCES}

1. Hombach J. Vaccines against dengue: a review of current candidate vaccines at advanced development stages. Rev Panamericana Salud Pública. 2007;21:254-60.

2. Brasil. Ministério da Saúde. Sistema de Informações de Febre Amarela e Dengue. SISFAD. [cited: 2010 Sept 28.

3. Brasil. Ministério da Saúde. Programa Nacional de Controle da Dengue (PNCD). Brasília: Fundação Nacional de Saúde; 2002. 51p.

4. World Health Organization. A review of entomological sampling methods and indicators for dengue vectors. Available from: http://www.who.int/tdr/publications/publications/ pdf/dengue_review.pdf.

5. Brasil. Ministério da Saúde. Diretrizes nacionais para prevenção e controle de epidemias de dengue. Brasília: Secretaria de Vigilância em Saúde; 2009. Available from: www. saude.gov.br/svs.

6. Tun-Lin W, Kay BH, Barnes A. Understanding productivity, a key to Aedes aegypt surveillance. Am J Trop Med Hyg. 1995;53:595-601.

7. Donalisio MR, Glasser CM. Vigilância entomológica e controle de vetores do dengue. Rev Bras Epidemiol. 2002;5:259-72.

8. San Martín JL, Brathwaile-Dick O. La estratégia de gestión integrada para la prevención y el control del dengue en la región de las Americas. Rev Panam Salud Publica. 2007;21:55-63.

9. Brasil. Ministério da Saúde. Mudança de uso de inseticidas larvicidas e adulticidas na rotina do Programa Nacional de Controle da Dengue. Brasília: Programa Nacional de Controle da Dengue; 2009. (Nota Técnica n 146/2009 CGPNCD/DEVEP/SVS/ MS).

10. Coelho GE. Dengue: desafios atuais. Epidemiol Serv Saúde. 2008;17:231-3.

11. Brasil. Instituto Brasileiro de Geografia e Estatística. Pesquisa Nacional de Saneamento Básico - 2008. [Cited: 2010 Sept 28]. Available from: http://www.ibge.gov.br/ home/presidencia/noticias/noticia_visualiza.php?id_noticia=1691\&id_pagina=1 dia 28/09/2010.

12. Suaya JA, Shepard DS, Siqueira JB, Martelli CT, Lum LC, Tan LH, et al. Cost of dengue cases in eight countries in the Americas and Asia: a prospective study. Am J Trop Med Hyg. 2009;80:846-55.

13. Honorio NA, Codeço CT, Alves FC, Magalhães MA, Lourenço-de-Oliveira R. Temporal distribution of Aedes aegypti in different districts of Rio de Janeiro, Brazil, measured by two types of traps. J Med Entomol. 2009;46:1001-14.

14. Kroeger A, Lenhart A, Ochoa M, Villegas E, Levy M, Alexander N, et al. Effective control of dengue vectors with curtains and water container covers treated with insecticide in Mexico and Venezuela: cluster randomised trials. BMJ. 2006;332:1247-52. doi: 10.1136/bmj.332.7552.1247.

15. Burattini MN, Chen M, Chow A, Coutinho FA, Goh KT, Lopez LF, et al. Modelling the control strategies against dengue in Singapore. Epidemiol Infect. 2008;136:309-19.

16. Luz PM, Vanni T, Medlock J, Paltiel AD, Galvani AP. Dengue vector control strategies in an urban setting: an economic modelling assessment. Lancet. 2011;377(9778): 167380. DOI:10.1016/S0140-6736(11)60246-8. 